\title{
A Multidisciplinary Attempt at Understanding the Violence in Mexico
}

\author{
José M. Rábade, and Francisco García García 2,* \\ ${ }^{1}$ Madrid Municipal Police Division for International Relations and University Complutense of Madrid, Spain \\ ${ }^{2}$ University Complutense of Madrid, Spain
}

\begin{abstract}
Mexico has been living with a level of violence that was unimaginable only a short time ago. Why and how has Mexico arrived at this dramatic increase in violence? The goal of this study is to reflect on this question through several disciplines. The idea is to collect and contrast sufficient information from the most varied fields of knowledge, including culture and art, as well as social sciences. This is done with the ambition that all these factors will help us to understand the reasons for this terrible and complex Mexican reality.
\end{abstract}

Keywords: Mexico, Organized crime, violence, complexity theory, culture.

\section{INTRODUCTION}

Mexico has been living with a level of violence that was unimaginable only a short time ago. According to several sources, about 50.000 violent deaths have occurred in the last 5 years, in what has been called "the war against drug trafficking".

Some investigations focus on the change of strategy against drug trafficking by the President of the Republic of Mexico, Felipe Calderón, as a cause of the significant increase of violence in Mexico. For others it is the result of the dynamics of confrontation between drug cartels.

Mexican journalist, Marcela Turati, asked the question in El País newspaper: "When did we get to this?" The goal of this work is to reflect on this question and to focus on some of its points, such as how and why Mexico has arrived at this dramatic level of violence.

To do so, a multidisciplinary nature approach is made, althought it's exploratory and a somehow heterodox.

Criminology is taken as a starting point, to subsequently go in depth into another art and culture related expressions, with the intention that, these different points of view will help us to get a better understanding of the reasons of this complex and terrible Mexican reality.

*Address correspondence to these authors at the Jose M. Rabade: Madrid Municipal Police Division for International Relations, CEO and Research Science Security Lab (http://sciencesecuritylab.com) and University Complutense of Madrid, Spain; Tel: 0034914864135 / 686529549; E-mail: joserabade@gmail.com

Francisco Garcia Garcia: Professor Audiovisual Communication and Advertising, College of Information Science, University Complutense of Madrid, Spain; Tel: 0034649186701 ; E-mail: fghenche@gmail.com
We believe that it is necessary to create an approach as wide and multidisciplinary as possible, even though that forces us to do an overview tour. The concept is to collect and corroborate enough information from the most varied fields of knowledge, including culture and art, as well as social sciences, with the ambition that all these factors will help us to understand the reasons for this terrible and complex Mexican reality. Violence, as many other issues that worry most people, cannot be solved without what $O$. Wilson (1999) calls "consilience", that is, the integration and synthesis of knowledge coming from natural sciences, social sciences and humanities.

\section{METHOD}

This study attempts to open new ways, by using a standpoint based on a combination of knowledge fields, related to social or human sciences and physical or nature sciences. Unfortunately, there are not many sources that present this kind of research under this multidisciplinary point of view.

It is appropriate to consider the posible viability of the use of the complex systems science on the criminological research. Althought the literature related to the use of complexity sciences to study the criminal behaviour is limited, Young (1991), Milovanovic (1997), Skogan (1986), carried out researches that might be supportive for the use of complex systems sciences in the criminologial theory.

With this goal in mind, we began collecting background bibliographic information about the situation from academic and scientific point of views. This information was complemented with other sources, which may not be as empirically accurate, but are still very interesting because of the valuable 
information they provide. With rigidity, specialization, and even a distancing given by the data of a more conventional analysis, (though scientifically rigorous) we add contrast with a different point of view. This is based on a variety of cultural and artistic expressions, which lead to the creation of new questions, and help to formulate interest in objective arguments for this investigation. This "style" comes from the analysis of some novels (called Narco-novels), essays, or journalistic investigations, and includes other artistic contributions, such as art, sculpture, performance, and music (Narco-corrido).

The "synthesis" of science, based on bibliographic explorations, and a tour through culture and art, will complete an approach that helps to better understand, the brutality Mexico suffers at this time.

\section{CONCEPT OF VIOLENCE AND ORGANIZED DELINQUENCY}

What do we mean by violence? The word violence, first appeared during the early 19th century. It comes from the Latin word, "vis", which means "force", "vigour", and defines a person with an irascible and brutal nature. It also defines a relationship based on strength and destined to subdue or oblige others. Unfortunately, there is not a clear and consistent definition that is globally accepted by the scientific community for the concept of violence.

J. San Martín $(2001,24)$ defines it as: the result of the interaction between natural human aggressiveness and culture. In a later expansion of this concept, he adds that it refers to a "specific human distinction that normally results from intentional actions (or threats) that tend to cause harm to others".

Social sciences have historically faced the definition of violence from two different positions: biologism and environmentalism. The first is an understanding that there's a biological determination of violence. Environmentalists, on the other hand, defend a social or cultural origin of violence (see San Martín, 2004, 2223). Between these two extremes, there is a position called interactionism that postulates that not everything is environmental or genetic, when it comes to the origin of violence.

The remaining issue is, according to $\mathrm{O}$. Wilson (1999, 187):

In what way does biology and culture interact, and particularly, how do they do it through every society to create common characteristics of human nature? What is it that ... links a thorough history of the species, which is mostly genetic, with more recent cultural stories of societies, when they are so far from each other?

It seems that "to the genetic evolution of natural selection has been added the parallel route of cultural evolution and, in some way, these two forms of evolution are connected". In the same line of thought, E. Carbonell $(2007,23)$ writes "human hominids have advanced on three organized and articulated legs: what are biologic, ethologic and technical behaviour'.

Due to these reasons, human behaviour is full of habits of ethologic behaviour similar to those of primates: aggressive behaviours: violence, war, the need for setting up borders among different groups, the presence of social hierarchies, etc. (E. Carbonell, 2003, $60)$. It seems there is no doubt that if we share these behaviours with our closest evolutionary relatives (chimpanzees and gorillas) violence would be the result of natural ethology, not a human cultural behaviour.

It is fundamental to mention the distinction Nelson Arteaga Botella $(2002,19)$ makes between two kinds of violence, what he considers direct violence and organized violence. The latter one is related to "a series of subconscious, indirect and impersonal human actions that cause individuals to be unable to reach their potential during their lifetime". It can be identified by social injustice, inequality of resources, etc. However, direct violence, though it can also be produced by organized violence, "is a corporal assault or any other kind, produced by war, vandalism, robbery, kidnapping, etc., that causes harm and in its extreme form includes murder".

Between these two forms of violence, there is a necessary mediation established by the State. Its role is fundamentally to try and reduce the level of organized violence, by reducing social injustice, and controlling, to the maximum extent possible, direct violence. We must not forget that the modern State possesses a monopoly on violence and is the only one able to exert proportional violence in a society with democratic guarantees.

From a criminologist (and penal) point of view, violence is associated with many kinds of infractions, which at the extreme is crime. Organized crime and therefore drug trafficking are consubstantial with an instrumental and systematic use of violence (as well as 
other intimidation practices. As we have mentioned before, violence in Mexico is mostly associated with drug trafficking and with the response of the State.

The term drug trafficking is not the right concept to demarcate the different businesses (legal and illicit ones) that drug cartels are associated with inside and outside of Mexico. The concept of organized crime or delinquency seems to be a more appropriate term when trying to reflect on what is happening in this Latin American country.

\section{How to define Organized Crime or Delinquency?}

It's not an easy task to define organized crime, especially because of the difficulty of including all related criminal acts in a single definition. The UN, in 2000 (at the Transnational Convention about Organized Delinquency) coined a concept about organized gangs which has significantly influenced international legislation: "an organized group formed by three or more people during a certain period of time that systematically acts with the intention to commit one or more serious crimes".

L. de la Corte Ibañez and A. Jiménez-Salinas (2010, 21) suggest that an organized crime group: "refers to every organization created with the express intention of obtaining and amassing economical profits, through its continued implication in illicit activities, and that assures its own survival, functioning and protection by using violence and corruption or creating confusion through legal companies".

The European Union, via the document Enfopol 161-REV-3 file, approved a series of indicators that demark the presence of an organized crime group. It is composed of 11 indicators, four of which have to happen simultaneously and include more than two individuals, actions which are long term, suspicion of serious crimes, and pursuit of profits and power. Some of the other optional indicators include distribution of specific tasks, existence of control procedures and internal discipline, use of politics, mass media, and justice, international activities, use of violence and intimidation, utilization of commercial and economic structures, and involvement in money laundering.

In conclusion, L. de la Corte (285) considers four basic modalities of violence connected to organized crime, each one of them with different targets and victims: disciplinary violence, intimidating and coercive violence against public servants and political authorities, illegal operations perpetrated with violence, and violence against other criminal organizations.

\subsection{Mexico and the International Policy Against Drugs, a Brief Historical Tour. Regulatory Framework in Drugs Policy}

Before trying to face the problem of the role of organized crime in the increase of violence, or if this huge rise of horror is attributable to a new strategy of the Mexican Presidency, we must try to understand the more recent history of drugs and organized crime in Latin America and Mexico.

When did the drug problem begin? It seems in the past, the control over the use of drugs was by nature, a local and individual issue. Its use varied in very obvious ways, depending on different human societies. However, despite the differences among cultures, it was subject to certain social rites that restricted or limited its use (Thouni, Francisco, E., 2009, 2, or A. Escohotado, 2004).

During the last 100 years, international regulations have been developed to establish a repressive control system. Antonio Escohotado attributes the growth of the United States into a world power as the main reason for the beginning of what he calls the crusade against drugs, both at an internal and international level, as well as its subsequent modifications and more restricted momentum (Escohotado, 2004, 603). In a critical way, he also questions the reasons and interests behind this regulation. He is surprised, for example, that "nobody seems to be amazed that the pharmacological crusade was started by an Anabaptist bishop and some American missionaries (Escohotado, $2004,25) "$. The fact that this regulation started in the USA cannot be omitted from the recent history of drugs in Mexico.

In any case, today there's an International Drug Control Policy (IDCP) based on three international conventions: the Single Convention on Narcotic Drugs in 1961 (rectified by the Protocol, in 1972), the Convention on Psychotropic Substances in 1971, and the the Convention Against Illicit Traffic of Narcotic Drugs and Psychotropic Substances in 1988. These treaties have a wide international adherence although it is true that there are more and more critical voices in Latin America.

This system is actually built on a basic principle: all the drugs controlled by the IDCP can only be used for medical and scientific research purposes. As a result, 
every recreational, social, experimental or ceremonial use is forbidden and considered as an abuse. The IDCP criminalizes any production, that is not used for medical or scientific purposes. However, it is more flexible about consumption, which can only be considered as an infraction of the law Thoumi, Francisco, 2011.

Could this new regime have contributed to the creation of a huge illicit drug market? According to Serrano $(2010,179)$ there is no doubt about it. According to this investigator from Mexico College, the fact that a lot of Latin American countries became producers, exporters, and important crossing points of illicit drugs, is closely connected to the enactment of the USA narcotic prohibition law and to the gradual consolidation of international governments' control of illicit drugs. Also, there are few doubts that this international war on drugs has played an essential part in the extraordinary increase of violence in Latin America. Today, Latin America is considered as one of the most dangerous and violent regions of the world. In fact, the homicide rate in some Latin American countries exceeds the global average by ten to one.

\subsection{The So-Called "War Against Drugs" and Mexico}

When did the illegal drug market in Mexico begin?

Drug trafficking is a phenomenon with a very long history in Mexico. Even before the prohibitionist regulation came into force, the first opium dens and Chinese mafia settled in the city of Mexicali (Bosh, Lolita 2010).

It is thought that opium poppy has been grown in Mexico since at least the last quarter of the $19^{\text {th }}$ century (1886) in the north-western State of Sinaloa. Early on (1870), there were attempts to control the trade of laudanum, poppy and marijuana, but with little success (Astorga, L. UNESCO). Marijuana farming and its commercialization was forbidden in Mexico in 1920, opium poppy was forbidden in 1926.

We should not be surprised that very quickly the North American prohibition caused the appearance of economies and illegal drug markets in Latin America, and particularly, at the Mexican border. In the period between 1930 and the end of the 60s, Mexico had already become a prominent producer of opium and marijuana (Serrano, 2010, op.cit.). The structure and the level of demand for drugs in the North American market suffered qualitative transformations and amazing increases related to war or counter-cultural movements from the beginning of the century. Mexican drug dealers (also Colombian) knew how to respond, over time, to this peak demand in the world's biggest drug market. For example, there were interesting circumstances in the illicit market such as when opium was forbidden in the USA while still being legal on the other side of the border; or during the alcohol prohibition in the USA (1920 - 1933), when this contraband became more popular than opiates like marijuana or cocaine.

It seems that, what really transformed drug trafficking into a high impact crime, with an ever increasing social impact, was the incorporation of Mexico along the cocaine traffic routes coming from the Andes. Although the beginning of this process dates from the 1970s, it was not until the 90s when the dismantling of the big Colombian cartels from Medellin and Cali led to Mexican drug dealer organizations becoming established as real factors of power in the country.

According to the sociologist Luís Astorga (2003) there are four very distinctive periods in Mexican drug trafficking history: 1914-1947; 1947-1985; 1985-2000; and the final one which begins on the $2^{\text {nd }}$ of July, 2000 and continues through 2006. Briefly, we will review part of this history based on this sociologist's work as well as the investigations of César Morales Oyarvide, Mónica Serrano and J. Chabat.

\subsection{Periods of Drug Trafficking History in Mexico. Organized Crime and Politics}

\section{The First Period (1914-1947)}

At this time, it is possible to find many examples of the relationship between the direction of Mexican politics and drug trafficking.

\section{The Second Period (1947-1985)}

According to L. Astorga, during this period, a series of structural relationships between political power and drug dealers were created, mainly represented by police organizations that, though they were in charge of security, also had illegal attributes to protect and contain drug dealers.

\section{The Third Period (1985-2000)}

The leading government party (PRI) begins to show signs of inability to control its own institutions of mediation, allowing the drug dealing organizations to 
acquire a greater autonomy relative to the political authority.

\section{The Fourth Period (2000-2006)}

On July 2nd, 2000, Mexicans decided to put an end, by vote, to what was likely the oldest State leading party in the world. The PRI was removed from executive power. They lost their absolute majority in the chamber, and the opposition party, Partido de Acción Nacional (PAN) rose to the main position of power.

This new scenario transformed the previous relationships of power, in which a symbiosis between legality and illegality was natural and where the PRI had been a cover and a wall of containment for over four decades. The new president, Fox, did away with some of the old inertias and initiated a greater political confrontation with the drug cartel.

\section{THE NEW ADMINISTRATION OF FELIPE CALDERON (2006-2012). NEW STRATEGY AGAINST NARCOTRAFFICKING}

At this point, we begin to approach one of the main goals of this study. It is essential to begin with a summary Jorge Chabat $(2010,29)$ makes about the situation, in terms of the security that Felipe Calderón inherited when he accepted the Presidency in December of 2006:

- $\quad$ There were certain areas of territorial control by drug cartels in several regions of the country.

- $\quad$ There was a war among drug cartels, which was a cause in part for the high level of violence.

- The government of V. Fox did not want to use public force against drug traffickers.

- There was a conflict with the USA due to the drug trafficking violence at the border.

- Despite V. Fox's anti-drug policy, the drug flow into the USA remained stable.

- It seems there was also a rise of illicit drug consumption in Mexico, mostly, from the 90s onward.

There's no doubt that during the previous period, and before the arrival of the new President, organized crime had become stronger, and the State organizations which tried to fight against it had become weaker. This situation, according to Felipe Calderón, had created a serious threat against the country's governability, which could not be ignored. However, other criticizing voices believe that as a result of his very poor electoral victory (some even call it a fraud), the new President made this "war against drug trafficking" a political move in order to deal with a certain crisis of legitimacy.

It's quite difficult to define the "unique" responsibility of this decision, with the results that we now know, although there is no doubt that the strategy of the Presidency generated a terrible loss of life for Mexican society.

Nevertheless, just like Carlos Zavala Sánchez, Lolita Bosh, Sergio González Rodríguez and L. Astorga, we must question if it is possible to think about the business of drug trafficking, as we know it today, without the involvement, in one way or another, of the State and its machinery responsible for fighting organized crime?, or can the growth of drug trafficking be explained without the support of political power? (Zavala, 2009, 100). Moreover, it is necessary to make an effort to investigate and ask about other possible players, which may not be as obvious as the cartels or certain levels of State, and which may be the real beneficiaries of this terrible situation.

There's no doubt that drug trafficking is strongly associated with economic or white collar crimes, although regrettably there are not many studies that examine how organized crime is linked to these other figures. We can not forget that some organized delinquency (which can be defined as being more evolved) usually coexists with political and economic elite (Gayraud, J.F., 2007, 395). Perhaps we are witnessing in Mexico a situation that reveals a more concealed international reality, an almost perfect confusion or mixture among politically and economically legal players and organized crime or mafias. (Gayraud, J.F., 2007, 396 and González Rodríguez, Sergio; 2014, 2009 and 2005)

\section{COMPLEX SYSTEMS SCIENCES AND CRIMINOLOGY}

Criminology has a relatively brief routing. We'll glance through some of its milestones. We could start by the first Lambroso studies, in 1870, until the publication of his famous Lúomo delinquente, in 1876. Or maybe, we could talk about the statistical - social researches from Guerry (1833) or Quetelet (1835) in the first decades of the 19th century, even before the 
classic Howard (1929), Bentham (1820), and Hommel (1772)

If we omit the fisrt or classic criminology, the so called Critical Criminology characterized the 20th century, with Sutherland (1939), Cressey (1964), Chicago's Human Ecology, anomie, criminal subcultures (stigmatization, deviation, organizational), the new criminological realisms, the situational, or the theoretical earthquake that Martinson (1974) caused with "Nothing works, everything's wrong". In short, although this approach was widely developed, it was exclusively focused on the university.

The new answer to this was a liberal, right-wing realism, characterized by Wilson (1975) on "Thinking about crime", wich sets out the reinforcement of law and order, followed by the "Zero Tolerance", hoisted by R. Guiliani, who counted on New York's Police chief, William Bratton's collaboration.

The new response was a left-wing realism, resulting from the study of the subculturals and the British left wing idealism, with Jock Young and J. Lea (1993) who expound that the criminal phenomenon is stronger in the poor and marginal sectors.

After this path, some certain theoretical dispute between the preponderance of the law and order, or the justice can be mentioned. Nowadays, there is an agreement, by taking the criminal phenomenom as a fact from reality, not a simple construction, besides rethinking the police role and work, and the reconsideration of the victim.

Finally, we can also mention another branches, such as situational criminology (Clarke 1993), biological nature studies (Jeffery, Clarence, 1979) neopositivists, postmodern (Madfis, Eric, 2013), pacification, feminist (Adler, Freda, 1979) or social control (Garland, D, 2001)

As Savelsberg and Sampson (2002) pointed, "criminology has a subject matter, but it doesn't have a single methodological commitment or a paradigmatic theoretical frame.May the so called complex systems sciences help to get a better understanding about violence in Mexico?

Complex systems sciences change the way we think about the science itself, and its role in society. It goes beyond the traditional reductionist standpoint, in which we focus in the parts of a system, to see the integration inside the network connections and the systems themselves. These connections produce the so called "emerging" behaviours we observe in several physical, biological, social, economic and technological systems. The emerging attributes prove that the whole is more tan the sum of its parts. Behind this, there a kind of collective behaviour science. By this way, physics have found a path in social sciences.

From a criminological point of view, Young (1998), on Chaos and crime, considers that "the solution for the delinquency is not about increasing law and order in all the circumstances", the final target would be getting a certain right amount of order.

"Chaos should not be reduced to fault or sin, as it holds the potencial for radical social transformation and constitutes creativity, variation, and spontaneity in human relationships".

Recent researches are studying the conflict from a complex systems perspective, for example Fellman, Phillip Vos, Bar-Yam, Yaneer, Minai, Ali A. (2015) on Clonfict and Complexity Countering Terrorism, Insurgency, Ethnic and Regional Violence, or Jean Marie McGloin, Christopher J. Sullivan and Leslie W. Kennedy (Editors), on When Crime Appears: The Role of Emergence (2011) is concerned with our ability to make sense of the complex underpinnings of the endstage patterns and events that we see in studying crime and offers an early narrative on the concept of emergence as it pertains to criminological research.

Graeme Chesters and lan Welsh (2005) have also studied the anti-globalization movements, from a complex and emerging point of view. Aaron Pycroft (2014) and Clemens Bartollas, on Applying complexity theory Whole systems approaches to criminal justice and social work, apply complexity to the penal justice and the social work.

Finally, Jeffrey T. Walker (2007) presents the viability of the use of the complex sciences in the criminological field. An example is drawn from social disorganization theory to demonstrate the ability of Complex system to explain crime at the neighborhood level, and Yaneer Bar-Yam (2005) on Making Things Work: Solving Complex Problems in a Complex World, focuses in how we can apply the complex systems ideas to help solving great challenges of real world, such as military war and the conflict, violence and ethnic terrorism.

This brief touring about complexity shows there are new links between social and human sciences, and 
violence could be treated attending to certain mechanistic models. However, when we talk about human behaviours and models under the complexity point of view. It is still difficult to decide when they are appropriate or they are just approximations.

\section{CULTURE AND ART AS AN ALTERNATIVE INTERPRETATION OF VIOLENCE IN MEXICO}

This paragraph arises from concerns that are based on the thoughts of some investigators and essayists about the limitations of social sciences' (although these limits are imposed by the restrictions of the scientific method) understanding of aspects, such as violence or corruption. Therefore, it is interesting to try to approach the problem of brutality in Mexico from a different perspective, based on culture, art, literature, painting or music.

Statements such as those made by Pablo I. Taibo II's are an inspiration to try to travel along these alternative paths:

"Corruption is an iceberg, and it's very difficult for journalism as well as social sciences, to narrate what is submerged. They often resign themselves to telling only about the visible part, about $10 \%$. Thriller novels narrate the whole iceberg".

There are other, more classical but no less interesting statements. Pablo Picasso said: "Art is a lie that approach us to the truth", or the author Virginia Wolf (on The Pargiters) said: "When the truth is important, I prefer writing fiction". Also appropriate for our goal is the definition of art made by $\mathrm{J}$. Wagenserber, "A form of knowledge based on the principle of communicability of complexities which are not necessarily intelligible".

Art helps us to see the world and brings us nearer to understanding realities which can go beyond that which is empirically demonstrable.

\subsection{Corrido and Narco Literature}

This route starts by looking at drug trafficking through two of the most innovative pillars of Mexican culture, the Corridos, or Narco-Corridos and the literature about drugs or Narco-Novels. In this sense, popular music through Corridos, and the literature of drug trafficking, provide a different kind of knowledge about the relationship between drugs and Mexico, power and inequality.
As Astorga says (1997), music has been the source that has given, to a wider audience, a different version of history. In this case, the Mexican Corrido shows the standing values, ethics, aspirations, and the stories of the lives of people related to the world of drugs. Mexican Corrido (or better, Corridos) are a venue for representing social realities, as well as being a way of protest, denouncement, and helping to document daily occurrences that are befalling the Mexican people (Grillo, loan, 2012, 272).

Caledonio Serrano Martínez (E. Molina, 2011) defines Corrido as "an epic - lyric - tragic musical genre that assumes every strophic form, includes all the genres; that uses all the poetic meters and all the combinations of rhyme, and is sung to the sound of a musical instrument and tells in a simple way all those events that left a deep mark on the sensitivity of the population". Among these events, Caledonio Serrano mentions the riots or the attempts at coup d'état, assaults, combats, catastrophes, murders, heroic deeds, and also corruption, adultery, betrayal, violence, kidnapping, prosecutions, patricide, damnation, fatalities, etc.

It appears as if its deepest origins had to do with Spanish ballads brought by the colonizers centuries ago (L.E. Molina, 2011); Later on, it could be linked with the songs known as Songs of the Revolution and Contraband (initially textile, later alcohol) from the late $19^{\text {th }}$ century and early $20^{\text {th }}$ century.

The Narco-Corrido should be understood today as a ballad of drug trafficking, as the musical chronicle of the fortune of two social actors: the protagonists of the production, distribution and drug consumption derived from the opium poppy, coca leaf and marijuana; and the agents responsible for fighting against it (Montoya Arias y Fernández Velásquez, 2009, 1).

Some of the characteristics of the Corrido are: criticism of authority, warning messages of a preventative type, listing the risks associated with the business of drugs, the injustice of poverty, and the denunciation of selective laws that work for the poor, but not for the rich. Many of the lyrics vent criticism about the arbitrariness and the legal excesses (supposedly) that are inherent with power (C. Héau Lambert, 2007, 53).

Astorga (1997) points out that there is a very remarkable contrast between official speech that is reflected by the mass media and that generated by the 
Corridos songwriters. Political speech considers the drug dealer as the bad guy, since he breaks the law, he trades with stigmatized goods and furthermore uses armed violence to achieve his purposes. In contrast to this narrative, the Corrido usually describes drug dealers as the good guys for the same reasons, because they have the required attributes to be successful in the trade to which they were born or which they chose (Astorga, 1997). The lyrics of the Corridos talk about the scope of the illegality and violence of narcotics, as well as narrating varied and entwined perspectives about how to understand and face the reality of drug trafficking.

Who are the characters in Corridos? The majority of the social agents that shape the drug trafficking field are represented in Corridos. In the beginning, they were real or mythical men and women who carried relatively modest (compared with the current standards) amount of marijuana, opium, heroin or cocaine. These characters have evolved over time, from crossing over to "the other side" (or crossing the border to the USA), by walking or swimming, to doing it by truck or by small planes. The classic use of guns has changed to using a "Ram's horn" (AK-47 machine guns), grenades and grenade launchers.

Also on the scene are drug growers or rural farmers, the "drug mules" who transport the goods, minor drug dealers or big drug leaders, imaginary or real. We cannot dismiss the police, soldiers, and corrupt politicians, usually without a proper name "who had contributed in a very special way to the drug dealers' successful business". We should highlight that, so far, businessmen and bankers are absent from Corridos' lyrics.

We cannot finish without mentioning one of its most famous representatives, Los Tigres del Norte, under the direction of Paulino Vargas Jiménez which has achieved great and popular, musical hits. For example, in their 1989 album, "Corridos Prohibidos", they denounced everything concerning the murdered DEA agent (Enrique Camarena), reaffirming this music as a protest by the people against elite speech. Other relevant groups are Los Broncos de Reynosa, Carlos y José, Los Alegres de Terán y Los Doñenos de Mario Montes y Ramiro Carvazos.

Probably, the most accurate interpretation about Corridos belongs to $\mathrm{C}$. Héau Lambert. According to this investigator "listening to or singing Narco-Corridos is, for the majority of the recipients a symbolic protest against those in charge of current political power and the injustice of a system that voids opportunities for the majority, especially the youth". In summary, "it is a venue for daily resistance or a weapon for the weak".

\subsection{Narco-Literature, the Narco-Novel (also known as North Narrative or even Desert Narrative)}

It seems that the first significant appearances of the topic of drugs in Mexican literature would be in the "Literatura de la Onda". This movement was a countercultural response which identified with the hippy movement from the 60s. However the consumption of drugs in this movement is mostly related to attempts to break away from social rules imposed by adults ( $L$. Molina, 2011, 59-60).

We could describe the Narco-Narrative as a series of contemporary texts that use the context of drug trafficking and its culture to represent practices, such as drug consumption, organized crime, underlying violence related to drug trafficking, and the new scale of social values in which consumerism and the value of money come first (L. E. Molina, 2011). Narco-Art may appear to be a new trend, but as the writers Lolita Bosch and Gabriela Polit say, the topics it addresses: death, violence, the border, social marginality, wealth and power..., have always been present in all forms of Mexican cultural expression.

What is undeniable is that in a few years, the production of this narrative has grown remarkably with novels or essays from authors, among others, like Yuri Herrera, Elmer Mendoza, Marcela Turati, Sergio González Rodríguez or Enrique Osorno. As a matter of fact, as Gabriela Polit states: "What defines Latin America today are its violent novels, about extremely violent cities..." when only a short time ago, they talked about dictators or about magic realism.

Narco Literature explores and denounces the different forms of discourse that are part of the drug trade and the way individuals change as they become involved in the dynamics of drug trafficking (as in Manis Joplin's lover, from Elmer Mendoza). These texts usually recreate the cultural changes caused by the socalled war against drugs. They point out the consumerism fever of our society and the violence throughout life on this continent but they also highlight real people - powerful Capos, but also marginal beings, for whom drug trafficking becomes a (or sometimes the only) life choice. This narrative reflects how drug trafficking has allowed young people from 
marginal neighbourhoods to rise through social classes and quickly prosper in settings previously inaccessible to people of their status and social class.

\subsection{Other Artistic Approaches to the Brutality}

Contributions are being made in an attempt to "narrate" or understand Mexico's violent reality from other artistic perspectives, such as sculpture writing, performance, painting or photography.

An extremely interesting artist is Rosa María Robles. It is believed that one of her most impressive exhibitions was "Knives" (Culiacán 2007). In this exhibition, she included a piece called "Red Carpet"; this carpet had nothing in common with the exhibitionist catwalk used by rich and famous people, but with the "Cobijas" or blankets in which people killed as a result of drug trafficking, are wrapped.

To create this piece, R. M. Robles gained access to a police station and obtained eight of these blankets. According to Juan Villoro, through this exhibition Robles achieved two goals: she brought to light one of the many unsolved crimes and demonstrated how easy it is to sneak into the legal system and appropriate items that should be firmly guarded (Villoro, J. 2008). Recognized writer Elmer Mendoza thinks that: "her work is a slap in the face of the collective conscience, ...her pieces are heart wrenching and even sinister, ...the work of this artist causes a feeling of anguish and loneliness".

In a similar form, Teresa Margolles (representing Mexico at the $53^{\text {rd }}$ Venice Biennial, in 2009) denounces violence through body parts and body fluids that she literally uses to permeate the exhibition of "Elements of the Dead". For example, in the previously mentioned Biennial, she presented a work called: What else could we speak about, if not? In this work, there's a room with the floor drenched in blood that visitors to the exhibit have to walk on. Teresa Margolles says: "the spectator walks on the wet floor and is connected to the Mexican bloodshed... He feels the presence of that murdered person under the soles of his shoes. He is physically connected to an unknown person who tragically died, but he also moves into the world that surrounded the victim, the life he lived, and the life his family and neighbours are currently living".

Margolles also showed in Venice a flag soaked in blood, cloth painted with mud from the place where victims from "this national war" fell after they were shot and jewelry made with pieces of glass from the shooting of car windshields.

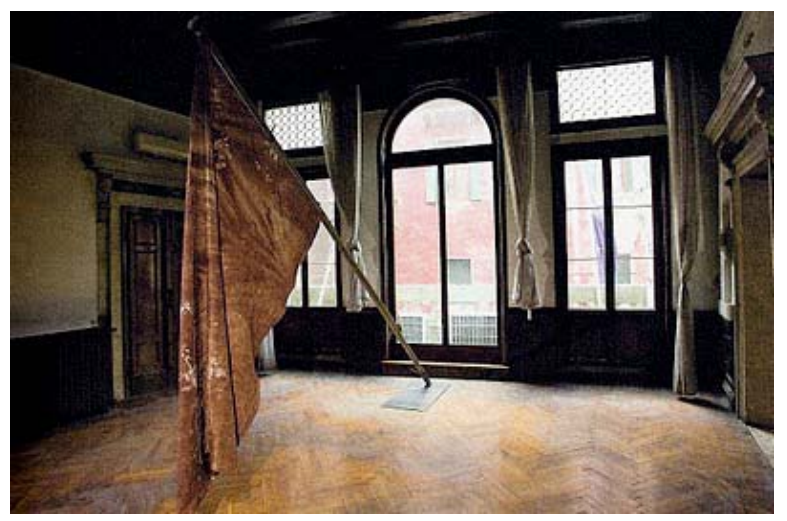

In another exhibition, called "Border" (May 2011, At the European cities of Kassel and Bolzano) she tried to magnify the events from Ciudad Juárez, by using very basic but impressive elements, such as a piece of wall riddled by bullets, or another blanket or "Cobija", used to wrap murdered people, as a flag.

\section{CONCLUSION (PARTIAL OF NECESSITY)}

It is not easy to make a summary, or consilience, of this attempt at a multidisciplinary tour. Though necessarily brief, it has attempted to provide a glimpse of Mexico's complex reality.

As was previously mentioned, drug trafficking was born in Mexico, dependent on the the political landscape. This symbiotic relationship has changed over the last few years, as drug dealers have achieved greater autonomy, even getting to the point of competing for areas of State power in some Mexican cities and regions (Naim, moisés, 2013, 190). The most dramatic case of loss of State power is probably Ciudad Juárez. This metropolis is currently considered one of the most dangerous cities on the continent. Murder, torture and the disappearance of women have exceeded the unimaginable. In 2011 nearly 2000 homicides were recorded, though this number is probably higher.

These words from Sergio G. Rodríguez (2005, III) brilliantly dissect this situation: "the misgovernment and the legal parallelism look like emblems of a false democracy, in which drug trafficking involves an inherent factor to the political system and absolutely not something external to it, like is usually said or believed".

The war against drug trafficking and the homicide statistical data, practically place Mexico in a situation of 
institutional collapse. This country has never suffered so much violence, except in its revolutionary period. The enormous amount of unpunished felonies, as a consequence of a very low rate of resolution of legal cases and sentencing, shows that Mexico may have lost control of the situation. More importantly, these facts call into question the ability of the State to govern.

However, it seems risky to support the hypothesis of many investigators, which state that this violence, unleashed since 2006, is mainly a consequence of the frontal strategy of fighting against drug trafficking set out by the President of the Republic. It can't also be omitted that Mexico is one of the countries where social inequality has grown more in a shorter period of time. (OECD, 2011:24)

We would like to put forth at this point another hypothesis, though it may be riskier. In this sense, Daniel Innerarity's idea seems very correct to us, (2004, 52) according to which: "in the $21^{\text {st }}$ society, everything is in sight". According to this, it appears that there is no obstacle at contemplating reality. It is shown in a vast number of mass media and information technologies. However, this wonderful Basque philosopher points out that this visibility has become problematic or fictitious.

If we apply his hypothesis about visibility of the problem of violencein Mexico, maybe we should conclude that there is a certain amount of blindness to the overwhelming excess of drama and its apparent protagonists (police/army/politicians versus organized crime). From this point of view, just watching the enormous daily tragedy of deaths is not the same as understanding them. The same way noise interferes wirh communication, the profusion of images can disguise reality (Innerarity, 2004, 53-54 and Kimberly Heinle, Octavio Rodríguez Ferreira, and David A. Shirk , 2014, 9-10)

Maybe we made a mistake by watching and talking about this reality under a binary method, of good and bad people, to describe violence in Mexico. In this sense, the so called complex science allow us to observe reality in a new way. Maybe we have focused on false clues. Maybe we must move across a grey area that usually avoids a more conventional analysis. Literature and art turn out to be an interesting resource that has helped to make visible what was invisible, or better, to allow us to see the other face of reality.

Sutherland already showed that the fighting systems against crime are very selective when it comes to criminalize individuals with a great economic power (1983). Generally, it is surprising that criminology focuses more in micro crimes or thiefs, than in economic - financial or political macrocriminality, which keep on having a very lower development but, nevertheless, they create structural and systemic problems. Pointing out, in an uncritical way, to the organized crime, to the cartels of the violence, helps us to omit another questions, such as the criminal behaviours of big financial entities, some multinationals, or political corruption.

In conclusion, we would like to propose other relevant issues to a new job: Is it possible that the huge illegal market mainly supported by drug trafficking in Mexico has something to do with the rest of those known as legal industries? Or, Is the illegal global economy, and particularly Mexico's, closely related to the legal economy? If so, how should we contemplate violence in Mexico now? Jean Maillard (2002, 48), Ramón Sáez (2014, 7-8), Sergio González Rodríguez $(2014,17)$ or Roberto Saviano $(2014,57)$ have no doubt about it and affirm that it is impossible to distinguish legality and illegality in the lawless world of the global financial planet.

"A drug cartel cannot use its infrastructure and logistic, and then invest, if it does not have a wide variety of companies and bank accounts; it has to be supported by totally honest industries and businessmen, intermediaries, administrative councils, financiers, attorneys..., or at least, they have to look so". (Jean Maillard, 2002, 48)

The economy set itself free from politics and public control, the deregulated worldwide market works free from any rules, the result is the absence of law in the international space (Ramón Sáez, 2014, 7-8).

Mexico is a defenceless society against the collusion of political and economic powers, for commission or omission, with organized crime (Sergio G. Rodríguez 2014, 17).

Those who ignore Mexico will never understand the fate of democracies transfigured by the flow of drug trafficking (R. Saviano, 2014, 57 and ss.).

It seems that, under this new perspective criminal actions, homicides, shootings, decapitations, tortures, and the horrible violence suffered by the Mexican people stops being something isolated, perfectly identifiable and easily attributed (to the drug dealer, the police or the army, in some cases, or to political 
culprits). Under this new view, organized crime, and cartels would be deeply rooted into the political, institutional and economic reality of today (Jean Maillard, 2002, 54). According to Anabel Hernández $(2010,587)$ :

"Drug cartel corruption has been assimilated in Mexico through the agencies in charge of defending the law and the procurement of justice, in the areas of State intelligence, of the militia and the police, of the governments of the Federation States, of the political parties, the legal system, the capital and the financial and banking systems. Never so many people suffered for so few".

Combined, this makes us contemplate Mexican violence with another perspective and makes us consider additional questions. It is left for a larger investigation, to discern if Mexico can be an (horrible) example of a greater global problem, a lawless economy, an out of control financial globalization based on massive and gross illicitness (Ramón Sáez 2014, 78), or an example of an experiment under a new global scenario based on control and surveillance (González Rodríguez, S., 2014, 10) that has allowed high crime, indistinguishable from the so called legal economy, to settle into the very heart of every democracy (Maillard, Jean., 2002, 135).

\section{REFERENCES}

ADLER, Freda, 1979. "Changing patterns", en AA.VV., The Criminology of Deviant Women, Boston, Houghton Mifflin,.

ARTEAGA Botello, Nelson. (2002) Tesis Doctoral. Una década de violencia en México 1990-2000. Universidad de Alicante.

ASTORGA, Luís. (2001) Límites de la política antidrogas en México. Revista internacional de ciencias sociales. №1, 169, pgns. 427-434

ASTORGA, Luís.(1999) Drug trafficking in Mexico: a first general assessment. UNESCO HQ Social Sciences. http://unesdoc. unesco.org/Ulis/cgi-bin/ulis.pl?catno $=117644 \&$ set= 4F9E70C3_1_334\&gp $=0 \& l i n=1 \& \| l=s$ (consultado agosto 2014)

ASTORGA, Luís. (1997). Los corridos de traficantes de drogas en México y Colombia. Latin American Studies Association

BENTHAM, Jeremy, Traités de Législation civile et pénal, 2.a ed., 3 tomos, París, Cosson, 1820.

BOSCH Lolita.(2010) El narco mexicano de hoy. http://blogs.publico. es/dominiopublico/1819/este-narco-mexicano-de-hoy/ (consultado agosto 2014)

BUSCAGLIA, Edgardo. La Paradoja Mexicana de la Delincuencia Organizada. ¿Más policías..... Más violencia organizada y..... Mas corrupción? ¿Hasta dónde?. http://www.institutodeaccionciudadana.org/docs/documentos/2.pdf (consultado agosto 2014)

CALEDONIO Serrano Martínez. En Luís Eduardo Molina Lora. Narrativa de drogas: una investigación transatlántica en la producción cultural de España, México y Colombia. Canadá, Tesis, 2011

CARBONELL, Eudald. (2003) Aun No somos Humanos. ED. Quinteto.
CARBONELL, Eudald. (2007). El nacimiento de una nueva conciencia. ED. Ara Llibres.

CORTE Ibáñez, L. y A. Jiménez-Salinas.(2010) Crimen.org, Evolución y claves de la delincuencia organizada. ED. Planeta, Barcelona.

CHABAT, Jorge. (2010). La respuesta del gobierno de Felipe Calderón al desafío del narcotráfico: entre lo malo y lo peor, 2010. pg. 21-40; En Los Grandes Problemas de México Seguridad Nacional y Seguridad Interior.

CHESTRES, Graeme and Welsh, Ian, 2006. Complexity and social movements: multitudes at the edge of chaos. International Library of Sociology, London: Routledge.

CLARKE, Ronald V., y FELSON, 1993. "Marcus, Routine Activity and Rational Choice", New Jersey, Transaction Publishers, pp. 1 13

MOLINA, Molina Lora. Luís E., (2011). Narrativa de drogas: una investigación transatlántica en la producción cultural de España, México y Colombia. Tesis Doctoral, Ottawa Canadá 2011

FELLMAN, Phillip Vos, Bar-Yam, Yaneer, Minai, Ali A. (2015) on Conflict and Complexity Countering Terrorism, Insurgency, Ethnic and Regional Violence.

FERNANDEZ Steinko, A., (2013). "Delincuencia, finanzas y globalización". Ed. CIS

FERNANDEZ Steinko, A., (2008). "Las pistas falsas del crimen organizado" Ed. Catarata.

GARLAND, David, 2001. The Culture of Control. Crime and Socia Order in Contemporary Society, Chicago, The University of Chicago Press.

GONZALEZ Rodríguez, Sergio (2005) Huesos en el Desierto. Barcelona, ED. Anagrama.

GONZALEZ Rodríguez, Sergio (2009) El hombre sin cabeza. Barcelona. Ed. Anagrama

GONZALEZ Rodríguez, Sergio (2014) Campo de Guerra. Barcelona. Ed. Anagrama (Premio Anagrama de Ensayo).

GAYRAUD, Jean-Francois.(2007). El G-9 de las Mafias en el Mundo. Geopolítica del Crimen Organizado. Barcelona, ED. Urano.

GUERRY, Michel André, Essai sur la Statistique Morale de la France, París Crochard, 1833.

GRAEME, Chesters and Ian Welsh, 2005 .Complexity and Social Movement(s):Process and Emergence in Planetary Action Systems Theory, Culture \& Society October 22:187-211

GRILLO, Ioan (2013). "El narco. En el corazón de la insurgencia mexicana". Ed. Urano, Barcelona

HEAU Lambert, Catherine. (2007) "El narco-corrido como relato de la vida". En ARENAS Revista Sinaloense de Ciencias Sociales Número 12. Cultura, arte y narco-corrido: los otros rostros de la trasgresión.

HERNANDEZ, Anabel., (2010): "Los señores del narco". Ed. Grijalbo.

HOMMEL, Karl Ferdinand, Über Belohnung und Strafe nach türkischen Gesetzen [1772], Berlín, Erich Schmidt Verlag, 1970.

HOWARD, John, The State of the Prisions [1777], Londres, J. M. Dent \& Sons Ltd., 1929.

Organized Crime Report Europe of Council (Informe Consejo de Europa sobre Crimen Organizado) (2005, p.19).

INNERARITY, Daniel. (2004) .La sociedad invisible. Madrid, Espasa.

JEFFERY, Clarence Ray, 1979 Biology and Crime, California, Sage Publications, pp. 114-118.

JEFFEREY T. Walker (2007) Advancing Science and Research in Criminal Justice/ Criminology: Complex Systems Theory and Non-Linear Analyses, Justice Quarterly, 24:4, 555-581. http://dx.doi.org/10.1080/07418820701717110

KIMBERLY, Heinle, Octavio Rodríguez Ferreira, and David A. Shirk (2014) Drug Violence in Mexico. Data and Analiysis Throug 2013. University of San Diego. https://justiceinmexico.files. wordpress.com/2014/07/dvm-2014-final.pdf 
LEA, John, y YOUNG, Jock, 1984 .What is to be done about Law \& Order? Crisis in the Eighties, 1.a ed., Middlesex, Penguin Books,. Posterior edición, 1993. What is to be done about Law \& Order? Crisis in the Nineties, 2.a ed., Londres, Pluto Press,

LOMBROSO, Cesare, 1896. L'Uomo Delinquente, in rapporto all'Antropologia, alla Giurisprudenza ed alle Discipline Carcerarie, 3 tomos, 5.a ed., Turín, Fratelli Bocca,.

MADFIS, Eric. 2013. "Postmodern Criminology." Entry in The Encyclopedia of Theoretical Criminology, edited by Chris Schreck, Angela Gover, and Wesley Jennings. Malden, MA: Wiley- Blackwell.

MAILLARD, Jean De., (2002) Atlas Akal de la criminalidad financiera. Del narcotráfico al blanqueo de capitales. Madrid, ED. Akal.

MARGOLLES, Teresa. (2009). Sangre para cambiar Mexico

http://www.publico.es/culturas/230663/sangre-para-cambiar-mexico. (consultado agosto 2014)

MARTINSON, Robert, 1974 -What works? Questions and answers about prision reform, en AA.VV., The Public Interest, n.o 35, Nueva York, National Affairs Inc., , pp. 48-50. Also published in MARTINSON, Robert; PALMER, Ted, y ADAMS, Stuart, 1976, Rehabilitation, Recidivism and Research, Nueva Jersey, National Council on Crime Delinquency, pp. 33-35.

MCGLOIN, Jean Marie, Sullivan, Christopher J., and Kennedy ,Leslie W. (Editors), 2011 on When Crime Appears: The Role of Emergence. NECSI/Springer co-publications

MENDOZA, Elmer. (2010) La Razon (de México) sábado 25 Domingo 26.9.2010 (razon.com.mx)

MOCHKOFSKY, Graciela. (2011 El País 29 noviembre). Mexico: el escalofriante récord de Calderón. http://blogs.elpais.com/ indias/2011/11/s\%C3\%A1bado-26-de-noviembrenoticia-enla-jornada-de-m\%C3\%A9xico-el-abogado-mexicanonetza\%C3\%AD-sandoval-present\%C3\%B3-ayer-ante-lacorte.html (consultado agosto 2014)

MONTOYA, Arias y Fernández Velásquez, (2009), El Narcocorrido en México.http://200.21.104.25/culturaydroga/downloads/ Culturaydroga14(16)_11.pdf (consultado agosto 2014)

OVALLE, L. Paola. Eros y tanatos: el narcocorrido y las reglas del narco. En ARENAS Revista Sinaloense de Ciencias Sociales Número 12. Cultura, arte y narcocorrido: los otros rostros de la trasgresión.

O. Walter, William III. 1989. Drug Control in the Americas. Alburquerque, University of New Mexico Press, (edición revisada) pp.17-18.

PARK, Robert Ezra; BURGESS, Ernest N., y MCKENZIE, Roderick Duncan, [1919, reimp. 1925] ,The City, 5.a imp., Chicago The University of Chicago Press, 1968.

POLIT, Gabriela. (2011, Domingo, 14 de agosto) Radar Libros. El otoño del sicario http://www.pagina12.com.ar/diario/ suplementos/libros/10-4368-2011-08-14.html (consultado agosto 2014)

PYCROFT, Aaron An BArtollas, Clemens (autor/editor) 2014. Applying complexity theory. Whole systems approaches to criminal justice and social work. Policy Press

QUETELET, Lambert Adolphe Jacques, Sur l'homme et le développement de ses facultés ou Essai de Physique sociale [1835], París, Librairie Arthème-Fayard, 1991
REGUILLO, Rossana. La narcomáquina y el trabajo de la violencia: Apuntes para su decodificación Instituto Tecnológico de Estudios Superiores de Occidente. http://hemisphericinstitute.org/hemi/es/e-misferica-82 (Consultado agosto 2014)

Ronquillo, Víctor (2004). Las muertas de Juárez. Crónica de una larga pesadilla. Madrid, ED. Temas de hoy, 2004

San Martín. J. (2004) .El laberinto de la violencia, causas tipos y efectos, Ariel Barcelona.

San Martín. J. (2001) La violencia y sus claves. ED. Ariel, Barcelona, $3^{\text {a }}$

SAVELSBERG, J. J., \& Sampson, R. J. 2002. Introduction to mutual engagement: Criminology and sociology. Crime, Law and Social Change, 37, 99-105. http://dx.doi.org/10.1023/A:1014552932605

SAVIANO, Roberto (2014) CeroCeroCero. Como la cocaína gobierna el mundo. Ed. Anagrama. Barcelona.

SERRANO, Mónica. (2007) México: narcotráfico y gobernabilidad. En la Revista Pensamiento lberoamerica №1, segunda época. 2007 Titulado Cohesión social en Iberoamérica: algunas asignaturas pendientes.

Serrano, Mónica.,.(2010) El problema del narcotráfico en México, una perspectiva latinoamericana. 2010. En "Los grandes problema de Mexico" Blanca Torres y Gustavo Vega.

SUTHERLAND, Edwin H.,1939. Principles of Criminology, 3.a ed., Filadelfia, J. B. Lippincott, 1939, pp. 4-9.

TAIBO II, Pablo. (2007 El País) Bajo el boom de los narcolibros. www.elpais.com/diario/2010/05/07/cultura/1273183202_8502 15.html (consultado agosto 2014)

THOUMI, Francisco E., 2009 "La normatividad internacional sobre drogas como camisa de fuerza". Nueva Sociedad, no 222, julio agosto de 2009.

THUOMI, Francisco. (2011, 20 noviembre) http://nuestraaparenterendicion.com/index.php?option=com_k2\&view=item\&id=7 72:francisco-thoumi-comparte-su-carta-abierta-al-presidentesantos-de-colombia-para-avanzar-en-el-debate-mundialsobre-las-drogas\& Itemid=122. (consultado agosto 2014)

TURATI, Marcela. Desde la Guerra Doméstica. (2012, El País 15 abril) http://internacional.elpais.com/internacional/ 2012/04/15/actualidad/1334522157_645059.html (consultado agosto 2014)

VILLORO, Juan. (2010, Febrero) http://www.sopitas.com/site/40722la-alfombra-roja-el-imperio-del-narcoterrorismo/ (consultado mayo 2014)

WILSON, Edgard O., 1999. Consilience. La Unidad del Conocimiento. Barcelona, ED. Galaxia Gutemberg-Círculo de Lectores..

WILSON, James Q.,1975. Thinking About Crime, Nueva York, Basic, Books, Inc., Publishers.

YOUNG, T.R. 1991 Chaos and crime: Explorations in postmoderm criminology. Red Feather Institute for Advance Studies of Sociology. Retrieved September 11, 2013, from http://critcrim.org/redfether/chaos/015crime.html

ZAVALA, Sánchez, Carlos, 2009. Estado y Narcotráfico: una relación encriptada. En Revista Sinaloense de Ciencias Sociales. Número 19. Entre la pobreza y la violencia, la literatura en América Latina.

\section{DOI: http://dx.doi.org/10.6000/1929-4409.2015.04.02}

(C) 2015 Rábade and García; Licensee Lifescience Global.

This is an open access article licensed under the terms of the Creative Commons Attribution Non-Commercial License (http://creativecommons.org/licenses/by-nc/3.0/) which permits unrestricted, non-commercial use, distribution and reproduction in any medium, provided the work is properly cited. 